\title{
Captive breeding of Margaritifera auricularia (Spengler, 1793) and its conservation importance
}

\author{
Keiko Nakamura ${ }^{1,2}$ (D) | Eva Elbaile ${ }^{1}$ | Carlos Salinas ${ }^{1}$ | Francesc Mesquita-Joanes ${ }^{2}$ (D) । \\ Ronaldo Sousa ${ }^{3}$ (D) | Joaquín Guerrero-Campo ${ }^{4}$ | Imanol Ruiz-Zarzuela ${ }^{5}$ (D) | \\ Ignacio de Blas $^{5}$ (D)
}

\footnotetext{
${ }^{1}$ Environmental Service Department, Sociedad Aragonesa de Gestión Agroambiental (SARGA), Zaragoza, Spain

2 "Cavanilles" Institute of Biodiversity and Evolutionary Biology, University of Valencia, Spain

${ }^{3}$ CBMA - Centre of Molecular and Environmental Biology, Department of Biology, University of Minho, Braga, Portugal

${ }^{4}$ Gobierno de Aragón. Servicio Provincial de Agricultura, Ganadería y Medio Ambiente, Zaragoza, Spain

${ }^{5}$ Laboratory of Fish Pathology, Faculty of Veterinary Sciences, Instituto Agroalimentario de Aragón (IA2) Universidad de Zaragoza,

Zaragoza, Spain

\section{Correspondence}

Keiko Nakamura, Sociedad Aragonesa de Gestión Agroambiental (SARGA),

Environmental Service Department, Ranillas Avenue, 5-A, 3 floor, 50018. Zaragoza, Spain.

Email: keikonakamura@hotmail.com

Funding information

Government of Aragón, Department of Rural Development and Sustainability
}

\section{Abstract}

1. Margaritifera auricularia is one of the most endangered freshwater mussels (Bivalvia, Unionida) in the world. Since 2013, the abundance of this species in the Ebro River basin (Spain) has sharply declined, driving the species to the verge of regional extinction. Therefore, any management measures that might facilitate the recovery of this species would be essential for its conservation.

2. During 2014-2016, captive breeding of M. auricularia allowed the production of $>10^{6}$ juveniles, out of which $95 \%$ were released into the natural environment, and $5 \%$ were grown in the laboratory under controlled conditions. The aim of this experimental work was to establish the best culture conditions for the survival and growth of M. auricularia juveniles in the laboratory.

3. The experiment was divided into two phases: phase I, in which juveniles recently detached from fish gills were cultured in detritus boxes until they reached a shell length of $1 \mathrm{~mm}$; and phase II, in which these specimens were transferred to larger aquaria to grow up to $3-4 \mathrm{~mm}$.

4. The best experimental conditions for juvenile survival and growth corresponded to treatments in glass containers at a density of 0.2 ind. $\mathrm{L}^{-1}$, using river water, with added substrate and detritus, enriched with phytoplankton, and avoiding extra aeration. The highest survival and growth rates attained, respectively, values of c. $60 \%$ at 100 days and $2.56 \mathrm{~mm}$ in shell length at 30-32 weeks.

5. This is the first study to report on the long-term survival and growth of juvenile $M$. auricularia in the laboratory, providing essential information in order to implement future conservation measures addressed at reinforcing the natural populations of this highly threatened species in European water bodies.

\section{KEYWORDS}

captivity, conservation, endangered species, freshwater mussel, growth, Margaritiferidae, survival 


\section{1 | INTRODUCTION}

Freshwater mussels (Bivalvia, Order Unionida) are considered one of the most threatened animal groups in the world, whose populations have suffered sharp declines in recent decades (Bogan, 1993, 2008; Lopes-Lima et al., 2014; 2018; Lydeard et al., 2004; Machordom, Araujo, Erpenbeck, \& Ramos, 2003; Neves, Bogan, Williams, Ahlstedt, \& Hartfield, 1997; Strayer et al., 2004). These declines are mainly caused by habitat loss and fragmentation (e.g. by dams and other type of physical structures), pollution and deterioration of water quality (e.g. from increased fine sediment deposition, excessive nutrient input, heavy metal accumulation, herbicides and fungicides used in agriculture), overexploitation (including exploitation of fish hosts), introduction of invasive alien species (IAS), and climate change (for a review see Lopes-Lima et al., 2017). Despite their threatened conservation status there is still a noticeable scarcity of information on their complex biology (Geist, 2010, 2011; Geist \& Auerswald, 2007; Howard \& Coffey, 2006; Lopes-Lima et al., 2014), particularly on their reproductive biology and on the fish-mussel relationship (Modesto et al. 2018), which may impair the implementation of effective conservation efforts (Ferreira-Rodríguez et al., 2019).

At present, one recognized way of helping to preserve these species is through captive breeding (Bolland, Bracken, Marin, \& Lucas, 2010; Gum, Lange, \& Geist, 2011; Moorkens, 2018; Preston, Keys, \& Roberts, 2007; Strayer, Geist, Haag, Jackson, \& Newbold, 2019). Indeed, Gum et al. (2011) stated that the captive breeding of endangered freshwater mussels can be an efficient tool to maintain the evolutionary potential of their populations, which otherwise would not resist long enough to benefit from the restoration of their habitats. Several projects have previously focused on captive breeding of several species of freshwater mussels, with significant advances during the past two decades (Hastie \& Young, 2003; Kovitvadhi, Kovitvadhi, Sawangwong, Thongpan, \& Machado, 2006; Lavictoire, Moorkens, Ramsey, Sinclair, \& Sweeting, 2016; Preston et al., 2007; Schmidt \& Vandré, 2010). Some studies tested different types of diet or substrate, as various culturing systems, to achieve the optimal conditions for the development of juvenile mussels (Barnhart, 2006; Beck \& Neves, 2003; Eybe, Thielen, Bohn, \& Sures, 2013, 2015; Gatenby, Neves, \& Parker, 1996; Gatenby, Parker, \& Neves, 1997; Liberty, Ostby, \& Neves, 2007). However, only a few projects reached the phase of reintroduction of the bred individuals into the natural environment (Araujo, Feo, Pou, \& Campos, 2015; Kyle, Reid, O'Connor, \& Roberts, 2017; Thielen, 2011). In Europe, special attention has been paid to the freshwater pearl mussel Margaritifera margaritifera (Linnaeus, 1758) with an important effort devoted to find the best captive breeding techniques (Denic et al., 2015; Eybe et al., 2013, 2015; Geist, 2010; Lavictoire et al., 2016; Moorkens, 2011; Scheder, Lerchegger, Jung, Csar, \& Gumpinger, 2014; Sime, 2016; Thomas, Taylor, \& Garcia de Leaniz, 2010).

More than 200 species of freshwater mussels are included in the IUCN Red List (Lopes-Lima et al., 2018; Lydeard et al., 2004; Prié, 2010). One of these is Margaritifera auricularia (Spengler, 1793), where the decline, both in abundance and distribution, has been estimated to be higher than $90 \%$, and is nowadays considered to be close to extinction (Araujo et al., 2009; Prié et al., 2018). It was formerly distributed in all the major rivers in western Europe, either in Mediterranean or Atlantic basins, including Belgium, Czech Republic, Denmark, France, Germany, Italy, Luxembourg, The Netherlands, Portugal, Spain, and the UK (Prié, 2010). The earliest citation of M. auricularia in Spain comes from the German malacologist Fritz Haas at the beginning of the $20^{\text {th }}$ century (Haas, 1916, 1917); however, it was later considered to be extinct, until 1985, when a few individuals were found in the lower Ebro River (Altaba, 1990). Later on, another extant population was found in the Canal Imperial de Aragón (CIA) in Zaragoza (Araujo \& Ramos, 1998). Today, its known distribution is restricted to the Ebro River basin in Spain (Altaba, 1990, 1997; Araujo \& Álvarez-Cobelas, 2016; Araujo \& Ramos, 2000a; 2000b; 2001; Gómez \& Araujo, 2008; Nakamura et al., 2018; Nakamura \& Guerrero, 2008) and four river basins in France: Charente, Vienne (Loire), Luy (Adour), and Dronne (Garonne) (Cochet, 2001; Lopes-Lima et al., 2017; Nienhuis, 2003; Prié et al., 2010, 2018). In Spain, c. 5700 individuals were recorded during the first decade of the $21^{\text {st }}$ century, most of them in $\mathrm{CIA}$, but since 2013 a drastic decline has been observed with a mortality of about 2500 individuals in this canal (Nakamura, Guerrero, Alcántara, Muñoz, \& Elbaile, 2018).

In M. auricularia, as in other freshwater mussels, the larvae (glochidia) need to infest the gills of a fish to complete their development (Modesto et al., 2018). When ready, the juveniles detach from the fish and fall to the river substrate. Supposedly, the former main fish host of M. auricularia in the Ebro River was the common sturgeon Acipenser sturio (Linnaeus, 1758), which inhabited the entire basin but is now locally extinct (Altaba, 1990; Araujo, Bragado, \& Ramos, 2001; Elvira, Almodóvar, \& Lobón-Cerviá, 1991; López, Altaba, Rouault, \& Gisbert, 2007). At present, the unique native species in the Ebro River basin suitable for the transformation of the glochidia of M. auricularia into viable juveniles is the river blenny Salaria fluviatilis (Asso, 1801) (Altaba \& López, 2001; Araujo \& Ramos, 2001). Nevertheless, experimental tests with non-native fish species have shown positive results, including the Siberian sturgeon Acipenser baeri (Brandt 1869), the Adriatic sturgeon Acipenser naccarii (Bonaparte, 1836) (Araujo, Quirós, \& Ramos, 2003; López et al., 2007), and the Czech sturgeon Acipenser ruthenus (Linnaeus, 1758) (Nakamura, unpublished results). The IAS Gambusia holbrooki (Girard, 1859) has also been identified as a viable host for M. auricularia in the Ebro River (Araujo et al., 2003; López \& Altaba, 2005). Recently, Soler, Boisneau, Wantzen, and Araujo (2018) reported the three-spined stickleback (Gasterosteus aculeatus Linnaeus, 1758) as another viable host.

Taking into account that M. auricularia is listed as Critically Endangered by the IUCN Red List and also included in Annex II of the Berne Convention and Annex IV of the Habitats Directive (Directive 92/43/ EEC; Council of the European Communities, 1992), a recovery plan was approved in 2005 (Decree 187/2005) for the region of Aragón, with emphasis on habitat protection and reinforcement of the population through a captive breeding programme. The main aim of this study was to determine which set of culture conditions could improve the survival and subsequent development of juveniles obtained by 
captive breeding. This information is essential for establishing a viable protocol for culturing this species and thereby facilitating the recovery of its populations in Europe.

\section{2 | METHODS}

\section{1 | Juvenile production}

Eighty-one M. auricularia adults were collected from CIA and Canal de Tauste (Zaragoza, Spain) in February 2014 and immediately transported, wrapped between damp towels inside cool boxes, to the aquaculture laboratory set in La Alfranca (Zaragoza, Spain). In February 2015, 71 adults were collected from the CIA and eight from the Quinto ditch (Zaragoza, Spain). In February 2016, 85 adults were collected for the breeding experiments: 65 from the CIA, 13 from the Canal de Tauste, and seven from the Quinto ditch.

Adult mussels were kept at room temperature $\left(10-12^{\circ} \mathrm{C}\right)$ in an Automatic Collection System to collect their glochidia as described by Nakamura, Elbaile, Muñoz, Catalá, and Salinas (2012). Six collecting systems were set, each consisting of a 1000-L tank connected to two containers of approximately $200 \mathrm{~L}$ each. Each small tank contained a 15- $\mathrm{cm}$ layer of gravel (particle size of $1-3 \mathrm{~cm}$ ) to allow the mussels to burrow into their natural position in the substrate. Water flowed out through flexible tubes to a $75-\mu \mathrm{m}$ sieve, which was partially submerged in order to maintain the collected glochidia under water. The sieve was checked for the presence of glochidia two or three times each day.

After collection of glochidia, the next step consisted of injecting a concentrated glochidia solution directly onto the gills of Siberian sturgeons. Before infestation, samples of glochidia solution were checked under the microscope to verify glochidia quantity and quality (following Araujo, Cámara, \& Ramos, 2002). These samples had a high concentration of glochidia of c. $2 \times 10^{6}$ ind. $\mathrm{L}^{-1}$, similar to values reported for the species in France (Soler, Wantzen, Jugé, \& Araujo, 2018).

The number of fish to be infested was calculated depending on their body size. Siberian sturgeons (mean weight of $1.5 \mathrm{~kg}$ ) were infested by directly injecting $20 \mathrm{ml}$ of the concentrated glochidia solution ( 2000 glochidia $\mathrm{ml}^{-1}$ ) onto their gills with a needleless syringe. Sixty sturgeons were infested in 2014, 100 in 2015 and 50 in 2016. The effectiveness of infestation was checked by direct observation of gills under a magnifying lens. The fish were kept in 3000-L tanks in the external grounds of the laboratory at temperatures ranging between 12 and $15^{\circ} \mathrm{C}$, until 2 weeks before the juveniles were expected to start detaching from their gills. At that time, fish were transferred to conical tanks inside the laboratory, at a density of 8-9 $\mathrm{fish} / \mathrm{m}^{3}$. These fish were kept unfed in order to avoid the mixing of detached juveniles with fish faeces. During the following 15 days, the temperature in the conical tanks increased to $20^{\circ} \mathrm{C}$ (May), when the first juveniles began to detach (amounting to c. 700 total degree-days, Araujo et al., 2003). Juveniles detached from fish were collected daily using a $120 \mu \mathrm{m}$ sieve, and the number of individuals was estimated from subsamples. Juveniles were subsequently used in the different experiments (described below) or reintroduced into the natural environment.

\section{2 | Juvenile mussel culturing}

\subsection{1 | Phase I: Detritus boxes}

The culture of juveniles of M. auricularia was based on the 'detritus boxes' method developed by Eybe et al. (2013) for M. margaritifera. The water for these boxes was collected from the Ebro River main channel upstream of the city of Zaragoza and filtered through a 7- $\mu \mathrm{m}$ sieve in 2014 and 2015 and an 18- $\mu \mathrm{m}$ sieve in 2016. Rectangular plastic containers (1-L capacity) were tested in 2014 and 2016, and glass containers in 2015 and 2016. Juveniles (mean shell size \pm standard deviation $=192 \pm 13.5 \mu \mathrm{m}$ ) were counted under a binocular microscope and allocated to experimental treatments in less than $24 \mathrm{~h}$. A density of 0.4 ind. $\mathrm{L}^{-1}$ (i.e. 200 juveniles in $500 \mathrm{ml}$ ) was set in 2014 and 2016. In 2015, two densities were tested: 0.2 ind. $\mathrm{L}^{-1}$ (100 juveniles in $500 \mathrm{ml}$ ) and 0.4 ind. $\mathrm{L}^{-1}$. Silica sand with a particle size of 400-800 $\mu \mathrm{m}$ was used as substrate (following Liberty et al., 2007 and preliminary tests). This sand was previously washed and dried in a furnace at $150^{\circ} \mathrm{C}$ for $24 \mathrm{~h}$. Detritus used in the boxes was collected weekly by trampling a flooded margin of the Ebro River containing abundant aquatic and riparian vegetation upstream of Zaragoza (Eybe et al., 2013). The collected sample was filtered through an $18-\mu \mathrm{m}$ sieve, and $25 \mathrm{ml}$ of the resulting water was added to each box. The composition of the detritus was assumed to be a mixture of organic matter, phytoplankton, zooplankton, fine sediments, and a large amount of bacteria and fungi in different proportions (Eybe et al., 2013; Gatenby et al., 1996; Hruska, 1999). Commercial phytoplankton (Reed Mariculture Inc. Campbell, California, USA) was used as additional food. As suggested by Eybe et al. (2013), $200 \mu \mathrm{l}$ (four drops) of Nanno $3600{ }^{\circledR}\left(68 \times 10^{9}\right.$ cells ml $\left.^{-1}\right)$ and $120 \mu$ l of Shellfish diet $1800{ }^{\circledR}$ (SFD; $2 \times 10^{9}$ cells ml ${ }^{-1}$ ) were diluted in $10 \mathrm{~L}$ of filtered river water. Nanno $3600 \AA$ is a monospecific concentrate of Nannochloropsis sp. (1-2 $\mu \mathrm{m})$, and SFD is a mixture of six different algae ranging between 4 and $20 \mu \mathrm{m}$ in diameter (Isochrysis sp., Pavlova sp., Thalassiosira weissflogii, Thalassiosira pseudonana, Chaetoceros calcitrans, and Tetraselmis sp.) Every 4 weeks the amount of food was increased in the same proportion $(+200 \mu \mathrm{l}$ of Nanno and +120 of SFD).

Boxes were maintained at a controlled temperature of $17-18^{\circ} \mathrm{C}$ and partly covered to restrict the light. Boxes were cleaned once per week and their river water was replaced by water enriched in a mixture of food and detritus (according to treatment conditions). Every week, the state of juveniles was checked under a binocular microscope. Those that were alive were counted and returned to the box, which had been previously cleaned and renewed. Dead individuals were removed to avoid proliferation of fungi (Eybe et al., 2013). During experiments carried out in 2014 and 2015, the three largest specimens from each treatment were photographed and measured weekly, 
using the Motic Image Plus@ software. In 2016, specimens were measured monthly using the same method.

Physicochemical parameters $\mathrm{pH}$, conductivity, dissolved oxygen, and temperature were monitored weekly using a multiparametric Thermoscientific ORION portable meter. Nitrite and ammonium concentrations were monitored using colorimetric kits (Visocolor ${ }^{\circledR}$ ECO). After 3 months, the periodicity for these analyses was adjusted to once per month (but always analysing in advance the new water to be used in the boxes).

During 2014, the boxes were checked for juveniles by filtering the substrate. Initially, 120- $\mu \mathrm{m}$ sieves were used, but mesh size was later increased to $250 \mu \mathrm{m}$ and further to $400 \mu \mathrm{m}$, following juvenile growth. To reduce shell damage observed during the filtering process, an alternative elutriation method (i.e. separation of particles according to their density, as described by Lavictoire et al., 2016) was used in 2015. This process consisted of using circular movements to separate juvenile mussels from the heavier substrate. The juveniles suspended in the water were then poured into the sieve, thus avoiding breakage by friction with sand particles.

A multifactorial experiment was carried out in 2014, with six different treatments and four replicates (detritus boxes) per treatment (Table 1). Each treatment conditions depended on the combination of adding substrate, detritus, phytoplankton, or extra aeration to filtered river water. The control treatment (Table 1, treatment 1), comprising only filtered river water, was used to verify that the juveniles did not survive in the long term without additional food. In 2015 , the number of treatments was reduced to three (selecting those that showed the best results in the previous year, with modifications in the amount of food added; see Table 1 for details), and the number of replicates varied from three to 15 . In 2016 the number of treatments was increased to 12 with the number of replicates ranging from three to nine (Table 1).

Based on the results obtained in 2014 some culturing conditions were modified in 2015 , including the type of container (from plastic to glass), the initial concentration of food (doubled), and the initial density of juveniles per box (reduced from 0.4 to 0.2 ind. $\mathrm{L}^{-1}$; Table 1, low density). The role of detritus was also tested by including three different treatments: with or without detritus, plus a highdensity treatment without detritus (Table 1).

In 2016, when juveniles were c. 100 days old (between June and September), they were transferred to phase II (aquaria) at a shell length of approximately $1 \mathrm{~mm}$. However, in the experiments carried out in 2014-2015, the cultured juveniles remained in phase I until December 2015 (see below).

Plastic containers were used again in 2016 to compare their performance with glass containers (Table 1 ). In addition, river water was compared with that from the $\mathrm{CIA}$, even though the canal water originates from the same river, and another type of food was tested:

TABLE 1 Treatments applied to juvenile mussel growth in detritus boxes throughout the study period (2014-2016). $\sqrt{\text { : }}$ present, x: absent

\begin{tabular}{|c|c|c|c|c|c|c|c|c|c|c|}
\hline Treatment & No. replicates & Year & Density & Container & Water & Phytoplankton & Detritus & Substrate & Feed Rate & Aeration \\
\hline 1 & 4 & 2014 & High & Plastic & River & $x$ & $x$ & $x$ & $x$ & $x$ \\
\hline 2 & 4 & 2014 & High & Plastic & River & $x$ & $\sqrt{ }$ & $\sqrt{ }$ & $x$ & $\sqrt{ }$ \\
\hline 3 & 4 & 2014 & High & Plastic & River & Marine & $\sqrt{ }$ & $x$ & Weekly & $\sqrt{ }$ \\
\hline 4 & 4 & 2014 & High & Plastic & River & Marine & $\sqrt{ }$ & $\sqrt{ }$ & Weekly & $x$ \\
\hline 5 & 4 & 2014 & High & Plastic & River & Marine & $x$ & $\sqrt{ }$ & Weekly & $\sqrt{ }$ \\
\hline 6 & 4 & 2014 & High & Plastic & River & Marine & $\sqrt{ }$ & $\sqrt{ }$ & Weekly & $\sqrt{ }$ \\
\hline 7 & 12 & 2015 & Low & Glass & River & Marine & $x$ & $\sqrt{ }$ & Weekly & $x$ \\
\hline 8 & 3 & 2015 & High & Glass & River & Marine & $x$ & $\sqrt{ }$ & Weekly & $x$ \\
\hline 9 & 15 & 2015 & Low & Glass & River & Marine & $\sqrt{ }$ & $\sqrt{ }$ & Weekly & $x$ \\
\hline 10 & 9 & 2016 & High & Glass & River & Marine & $\sqrt{ }$ & $\sqrt{ }$ & Weekly & $x$ \\
\hline 11 & 3 & 2016 & High & Glass & River & Marine & $\sqrt{ }$ & $\sqrt{ }$ & Daily & $x$ \\
\hline 12 & 5 & 2016 & High & Glass & Canal & Marine & $\sqrt{ }$ & $\sqrt{ }$ & Weekly & $x$ \\
\hline 13 & 3 & 2016 & High & Glass & Canal & Marine & $\sqrt{ }$ & $\sqrt{ }$ & Daily & $x$ \\
\hline 14 & 3 & 2016 & High & Glass & River & Freshwater & $\sqrt{ }$ & $\sqrt{ }$ & Weekly & $x$ \\
\hline 15 & 3 & 2016 & High & Glass & Canal & Freshwater & $\sqrt{ }$ & $\sqrt{ }$ & Weekly & $x$ \\
\hline 16 & 9 & 2016 & High & Plastic & River & Marine & $\sqrt{ }$ & $\sqrt{ }$ & Weekly & $x$ \\
\hline 17 & 3 & 2016 & High & Plastic & River & Marine & $\sqrt{ }$ & $\sqrt{ }$ & Daily & $x$ \\
\hline 18 & 5 & 2016 & High & Plastic & Canal & Marine & $\sqrt{ }$ & $\sqrt{ }$ & Weekly & $x$ \\
\hline 19 & 3 & 2016 & High & Plastic & Canal & Marine & $\sqrt{ }$ & $\sqrt{ }$ & Daily & $x$ \\
\hline 20 & 3 & 2016 & High & Plastic & River & Freshwater & $\sqrt{ }$ & $\sqrt{ }$ & Weekly & $x$ \\
\hline 21 & 3 & 2016 & High & Plastic & Canal & Freshwater & $\sqrt{ }$ & $\sqrt{ }$ & Weekly & $x$ \\
\hline
\end{tabular}


Algamass (Microalgae Solutions S.L.; $\sim 60 \times 10^{9}$ cells ml $^{-1}$ ), composed of a mixture of freshwater microalgae: Chlorella vulgaris (Beijerinck, 1890) (40\%), Scenedesmus quadricauda (Brebisson, 1835) (40\%), Neochloris oleobundans (Chantanachat \& Bold, 1962) (12\%), and Pinnularia viridens (Ehrenberg, 1843) (8\%). The initial diet was adjusted using $600 \mu \mathrm{l}$ of concentrated Algamass, diluted in $10 \mathrm{~L}$ of river water, which was increased monthly. A new feeding treatment was also tested, in which a concentrated solution was added daily rather than weekly (only checked with the marine phytoplankton).

\subsection{2 | Phase II: Aquaria}

By the end of 2015 and the beginning of 2016, phase II began, using 20 - $\mathrm{L}$ aquaria $(38.5 \times 21 \times 25 \mathrm{~cm})$ with the same river water and substrate ( $1 \mathrm{~cm}$ thick), and adding a flow of $100 \mathrm{~L} \mathrm{~h}^{-1}$. Two drops of Shellfish diet $1800 \AA$ plus one of Nanno $3600 \AA$, previously diluted in water from the same aquarium, were added daily. One month later, the amount of food was increased to three and two drops, respectively. The aquaria were kept at room temperature $\left(12-23^{\circ} \mathrm{C}\right)$ and in semidarkness. In December 2015, the surviving juveniles raised in detritus boxes during 2014 (18 individuals) and 2015 (55 individuals) were transferred to phase II.

In 2016, those juveniles from the detritus boxes (phase I) that were fed with marine phytoplankton and attained $1 \mathrm{~mm}$ in shell length were transferred to aquaria (200 juveniles per aquarium). These juveniles had detached from fish gills in May, and by August the first ones had reached $1 \mathrm{~mm}$. Nine aquaria were set up, all with the same experimental conditions, the only difference among them being the age of the individuals upon entering phase II (i.e. the first aquaria were set with those juveniles that had attained earlier the largest size). Aquarium 1 was filled during the last week of August, and aquaria 2 and 3 were filled during the first and second week of September, respectively. Aquaria 4-9 were filled during the second week of October. All the remaining juveniles from phase I fed with marine phytoplankton (about 450 juveniles), which were still alive but smaller than $1 \mathrm{~mm}$, were transferred to the last aquaria (8 and 9). Juveniles present in these two aquaria were later combined owing to the high mortality. The results from both these aquaria were analysed together (as 8-9).

Two additional aquaria (10 and 11) were added to the experiment the last week of October with the latest juveniles coming from treatments fed with freshwater phytoplankton. These juveniles were then fed with marine phytoplankton. The density of these aquaria was set to 450 juveniles per aquarium instead of 200 .

The size of the three largest individuals was measured once per month. The physicochemical parameters were checked weekly in order to control the potential rise of nitrite and ammonium in the water (following the same procedure as described above), partly renewing it if necessary. During the first months, the aquaria were cleaned every 2 weeks, extracting the juveniles first and then replacing the water and rinsing the substrate. After week 28 , cleaning took place every 3 weeks.

\section{3 | Statistical analysis}

Kaplan-Meier survival analysis (with the log-Rank test) was used to compare survival between years (up to day 100 before the start of phase II), between treatments during phase I for each year, and between treatments during phase II for year 2016.

Cox's regression with direct selection (also using data up to day 100) was used to test for the effects of different factors within each treatment, separately for each year.

The Shapiro-Wilk test was applied to check for normality in growth data. Mann-Whitney analysis was used to compare growth between years. Only those treatments with the highest growth each year were compared, i.e. one for 2014 and one for 2015. In 2016, comparisons were performed between the two treatments with highest growth rate, fed with marine phytoplankton, and between the two with added freshwater phytoplankton.

A Spearman's correlation coefficient was calculated with data from aquaria 1 to 8-9 (fed with marine phytoplankton) to check for a relationship between survival in phase II and the day juveniles entered this phase.

All statistics were performed using IBM SPSS 19.0 for Windows (IBM, Chicago, IL, USA) and the significance level was set at 0.05 .

\section{3 | RESULTS}

\section{1 | Juvenile production}

During the breeding experiments in 2014-2016, >10 $0^{6}$ juveniles were collected in the laboratory, with a maximum number of 670,000 juveniles achieved in 2016 (Table 2), of which c. 5\% were used in the experiments and $95 \%$ were released into the natural environment.

\section{2 | Survival and growth}

Survival rate at the end of the first 100 days during phase I was different among the 3 years of experiments $(P<0.001)$, being highest in 2016 (58\%), followed by 2014 (41\%) and 2015 (37\%; Figure 1).

In 2014, treatment 4, corresponding to a high density of juveniles with river water, added marine phytoplankton, detritus, and substrate, fed weekly, and with no extra aeration, produced the best results in terms of survival and growth rate (Figures $2 a$ and 3 ). When comparing treatments 2 and 6 (Table 3), which had the same experimental conditions except for the supplementary food in treatment 6 , treatment 2

TABLE 2 Juvenile production per year and amount assigned to captive breeding

\begin{tabular}{|llc|}
\hline Year & $\begin{array}{l}\text { Estimated juvenile } \\
\text { production }\end{array}$ & $\begin{array}{l}\text { Number of juveniles } \\
\text { breeding in captivity }\end{array}$ \\
\hline 2014 & 114,600 & $112,400(98.0 \%)$ \\
\hline 2015 & 462,084 & $7,169(1.5 \%)$ \\
\hline 2016 & 670,000 & $30,000(4.5 \%)$ \\
\hline
\end{tabular}




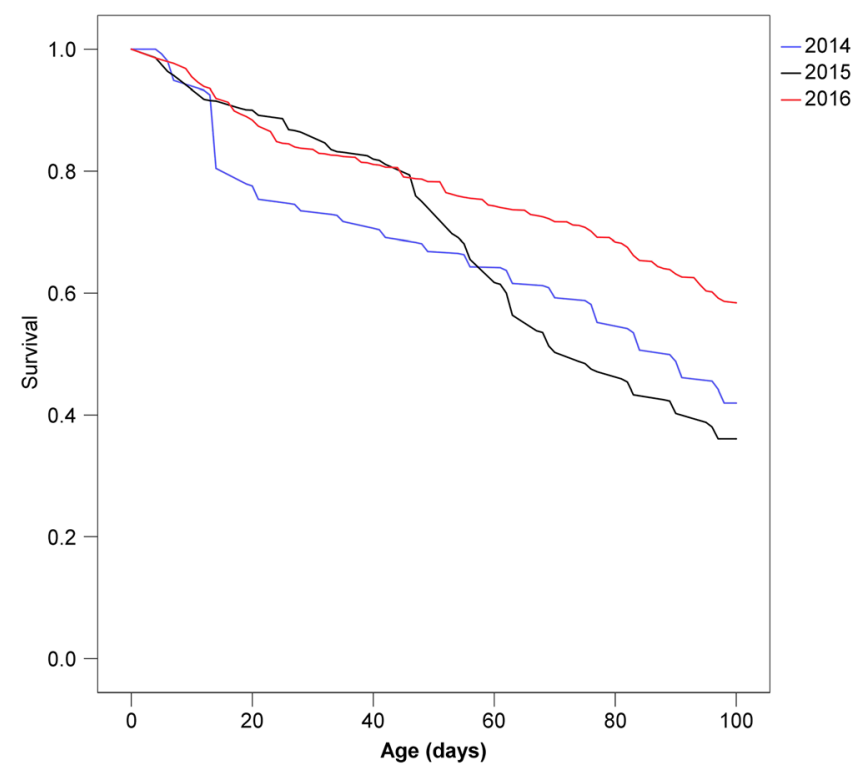

FIGURE 1 Global survival of Margaritifera auricularia juveniles in phase I up to day 100 , for each year of the experiment across treatments (See Table 1 and text for further explanation) showed a lower mean survival time (65 days) compared with treatment 6 (79 days). Comparing survival time with or without substrate (treatments 3 vs. 6), its presence resulted in an increased mean survival time by c. 19 days $(P<0.001)$. Comparisons between treatments 4 and 6 suggest a negative influence of aeration, which decreased the mean survival time from 86 to 79 days $(P<0.001)$. The effect of detritus (treatments 5 vs. 6 ) was not significant $(P=0.567)$. The results of Cox's regression for 2014 confirm that the presence of substrate and phytoplankton significantly reduce mortality in about $50 \%$ compared with those treatments without (hazard ratio c. 0.5; Table 4) and the added aeration increased the probability of mortality by 2.3 times compared with treatments with no aeration.

In 2014, juveniles were maintained in phase I until December 2015, so growth was relatively slow. Shell lengths of 1 and $2 \mathrm{~mm}$, respectively were reached during weeks 28 and 48-49 (Figure 3). At that point, an increased growth rate was observed, but it also coincided with the mortality of the largest juveniles, driving a decrease in mean length a few weeks later (week 52). Exponential growth did not occur in this cohort until the next spring (May 2016), around week 95-100 (Figure 3). Juveniles raised in 2014 reached $1 \mathrm{~cm}$ in length at week 115.
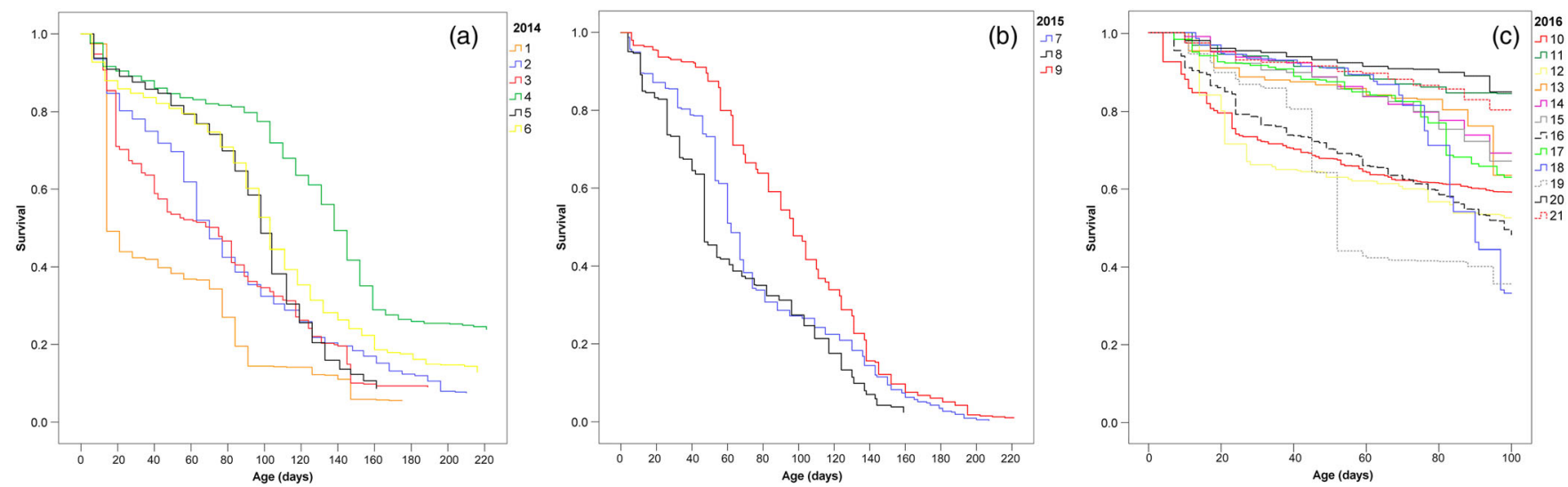

FIGURE 2 Proportion of Margaritifera auricularia juveniles surviving in each treatment in phase I, years 2014 (a), 2015 (b), and 2016 (c). Treatment codes as in Table 1

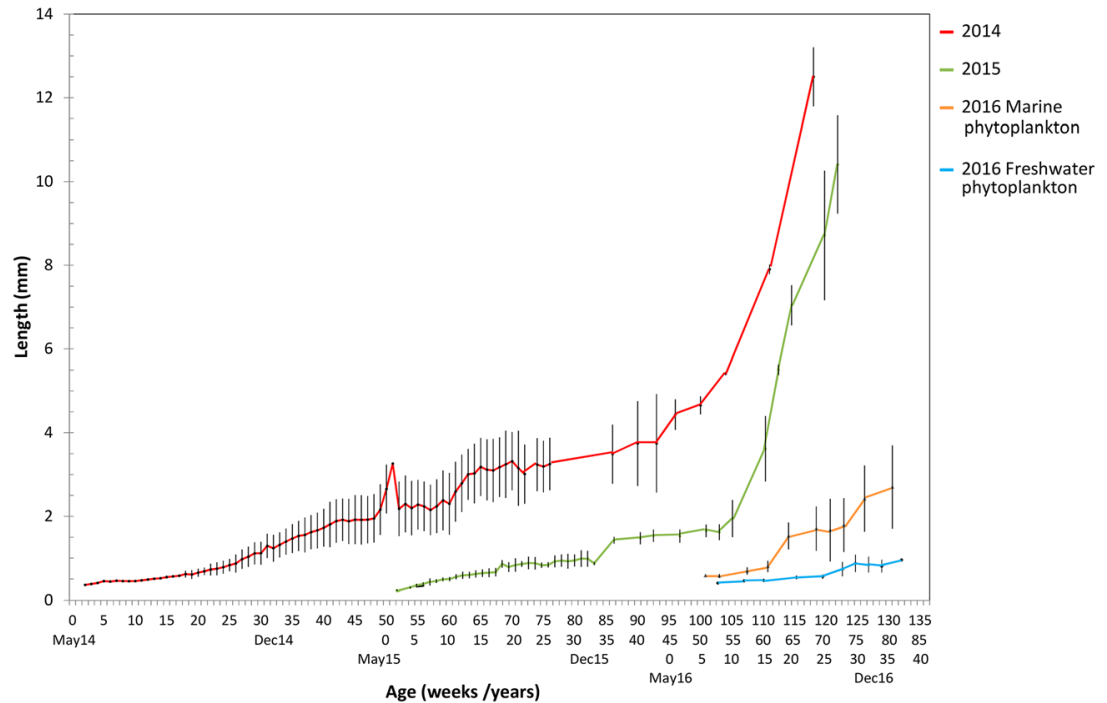

FIGURE 3 Growth of Margaritifera auricularia juveniles throughout the study period. Red line: year 2014 (treatment 4). Green line: year 2015 (treatment 9). Orange line: year 2016, marine phytoplankton; week 1 to 17: phase I (treatment $10+16$ ); week 17 to 34: phase II (aquaria 1 to 8-9). Blue line: year 2016, freshwater phytoplankton; week 1 to 23: phase I (treatment $14+20$ ); week 23 to 34: phase II (aquaria 10-11) 
TABLE 3 Pairwise comparison of survival between experimental treatments according to variable tested, and selected conditions with the highest survival rates. Years 2014-2015 and 2016. See Table 1 for treatment explanation. (NS: not significant)

\begin{tabular}{|c|c|c|c|c|c|}
\hline Year & Variable & Treatment & Mean survival time (days) & $P$-value & Selected conditions \\
\hline \multirow[t]{4}{*}{2014} & Phytoplankton & 2 vs. 6 & 65 vs 79 & $<0.001$ & With phytoplankton \\
\hline & Substrate & 3 vs. 6 & 60 vs. 79 & $<0.001$ & With substrate \\
\hline & Aeration & 4 vs. 6 & 86 vs. 79 & $<0.001$ & Without aeration \\
\hline & Detritus & 5 vs. 6 & 81 vs. 79 & 0.567 & NS \\
\hline \multirow[t]{2}{*}{2015} & Density & 7 vs. 8 & 64 vs. 57 & 0.002 & Low density \\
\hline & Detritus & 7 vs. 9 & 64 vs. 81 & $<0.001$ & With detritus \\
\hline \multirow{15}{*}{2016} & & 10 vs. 11 & 71 vs. 91 & $<0.001$ & Daily \\
\hline & & 16 vs. 17 & 72 vs. 85 & $<0.001$ & Daily \\
\hline & & 18 vs. 19 & 83 vs. 65 & $<0.001$ & Weekly \\
\hline & Phytoplankton & 12 vs. 15 & 68 vs. 86 & $<0.001$ & Freshwater \\
\hline & & 10 vs. 14 & 71 vs. 87 & $<0.001$ & Freshwater \\
\hline & & 16 vs. 20 & 72 vs. 93 & $<0.001$ & Freshwater \\
\hline & & 16 vs. 18 & 72 vs. 83 & 0.003 & Canal \\
\hline & & 17 vs. 19 & 85 vs. 65 & $<0.001$ & River \\
\hline & & 20 vs. 21 & 93 vs. 91 & 0.026 & River \\
\hline & Container & 12 vs. 18 & 68 vs. 83 & 0.078 & NS \\
\hline & & 11 vs. 17 & 91 vs. 85 & $<0.001$ & Glass \\
\hline & & 10 vs. 16 & 71 vs. 72 & 0.087 & NS \\
\hline & & 13 vs. 19 & 86 vs. 65 & $<0.001$ & Glass \\
\hline & & 15 vs. 21 & 86 vs. 91 & $<0.001$ & Plastic \\
\hline & & 14 vs. 20 & 87 vs. 93 & $<0.001$ & Plastic \\
\hline
\end{tabular}

In 2015, the highest survival and growth rates were obtained in treatment 9 (Figures $2 \mathrm{~b}$ and 3), with similar conditions as those described for 2014 but in a glass container and at a lower density. Adding detritus resulted in improved mean survival time (81 days instead of 64 days when comparing treatments 7 and 9; $P<0.001$; Table 3). Treatment 7, with low density, produced a higher survival time than treatment 8 (64 vs. 57 days, $P=0.002$ ). When testing the effects of different variables with Cox's regression (Table 4), the addition of detritus and reduced juvenile density increased survival by 2 and 1.2 times, respectively.
During 2015, shell lengths of 1 and $2 \mathrm{~mm}$ were reached during weeks 30 and 54, respectively (Figure 3). For juveniles bred in 2015, phase II started at week 32 , with an initial exponential increase in length during week 54 and a continuation of growth until they reached about the same size as individuals from the 2014 cohort. Indeed, the juveniles raised in 2015 reached $1 \mathrm{~cm}$ in length at week 70, almost 12 months earlier than those raised in 2014.

In 2016, treatments 20,11, and 21 showed the highest survival rates (Figure 2c); however, the growth recorded in treatment 20, and generally in treatments with freshwater phytoplankton, was lower

TABLE 4 Influence of the treatment variables on the survival rate of juveniles in the cultures, as tested with Cox's regression for each year (symbol $\uparrow$ and bold type indicate the variable conditions that favour survival)

\begin{tabular}{|c|c|c|c|}
\hline \multirow[b]{2}{*}{ Year } & \multirow[b]{2}{*}{ Variable } & \multicolumn{2}{|l|}{ Hazard ratio } \\
\hline & & (95\% confidence interval) & $P$-value \\
\hline \multirow[t]{2}{*}{2014} & Substrate: presence† vs. absence & $0.542(0.487-0.602)$ & $<0.001$ \\
\hline & Aeration: presence vs. absence $†$ & $2.327(1.983-2.730)$ & $<0.001$ \\
\hline 2015 & Detritus: presence $\dagger$ vs. absence & $0.510(0.465-0.558)$ & $<0.001$ \\
\hline \multirow{3}{*}{2016} & Type of water: rivert vs. canal & $0.751(0.709-0.796)$ & $<0.001$ \\
\hline & Container: plastic vs. glass $†$ & $1.235(1.165-1.308)$ & $<0.001$ \\
\hline & Feed rate: weekly vs. daily $†$ & $1.499(1.394-1.612)$ & $<0.001$ \\
\hline
\end{tabular}


when compared with juveniles fed with marine phytoplankton (Figure 3). Growth rate in treatments 10 and 16 were the highest recorded values. Therefore, in the balance between survival and growth, treatment 11 was selected as the one with the best results in 2016, despite the fact that the greatest survival was obtained with freshwater phytoplankton. When testing survival time by pairs of treatments for each variable, only four out of 20 comparisons were not significant (Table 3) and four categorical variables were significant according to Cox's regression in 2016 (Table 4). Both analyses suggest that the probability of survival is higher at daily rather than weekly feeding, and juveniles fed with freshwater phytoplankton showed higher survival (although reduced growth) than those with marine phytoplankton. Regarding water type, the highest survival was obtained with water from the Ebro River. The Kaplan-Meier analysis showed no clear patterns regarding survival time comparing treatments with glass or plastic containers; however, the glass container increased survival by 1.2 times when compared with the plastic container, according to the Cox's regression.

The survival of juveniles in phase II was very variable in 2016. The first three aquaria set up in August-September had a final survival rate above $80 \%$ after 120 days (220 total days since detached from fish) (Figure 4a). The remaining aquaria (4 to 8-9) presented lower survival, the lowest being in aquaria 8-9 with a mortality of almost $100 \%$.

The correlation between survival at the end of the year (December 2016) and the day of entry to phase II was negative and significant (Spearman's Rho: $-0.745 ; P<0.001$ ); that is, the later the juveniles enter phase II, the lower their survival rate, as happened in aquarium 7, and especially in aquaria 8-9 (Figure 4a). Aquaria 10 and 11, where juveniles were fed with freshwater phytoplankton during phase I, maintained a $70-90 \%$ survival rate at the end of the year (Figure 4b).

During 2016, growth in phase I was higher for juveniles fed with marine phytoplankton compared with previous years (Figure 3) and for those fed with freshwater phytoplankton in the same year. At week 17, juveniles fed with marine phytoplankton already exceeded $1 \mathrm{~mm}$ in length and, at the end of 2016 (week 32), they doubled the length reached in previous years at that age, with a mean $\pm S D$ of
$2560 \pm 998 \mu \mathrm{m}$ (compared with $1061 \pm 185 \mu \mathrm{m}$ in 2015 and $1236 \pm 323 \mu \mathrm{m}$ in 2014; Figure 3).

Juveniles fed with freshwater phytoplankton grew much slower and remained below $1 \mathrm{~mm}$ in length during the entire phase (Figure 3). Their growth rate was still very low in phase II, even though the type of food was changed to marine phytoplankton, and by week 32-33 they had not yet attained $1 \mathrm{~mm}$ in shell length $(896 \pm 19 \mu \mathrm{m})$.

\section{4 | DISCUSSION}

The results of this study show that M. auricularia can be cultured in the laboratory under a set of particular conditions that allow large numbers of viable juveniles to be produced in a few months. This has considerable implications for conservation, as juveniles of M. auricularia, a critically endangered species, have been successfully bred in relatively large numbers for the first time to an age older than 2 years and shell size $>1 \mathrm{~cm}$, thereby providing support for the recovery of its declining populations through captive breeding.

\section{1 | Phase I}

Hruska $(1999,2001)$ established for the first time a successful method for the breeding of juveniles of M. margaritifera using small containers and feeding them with detritus. Eybe et al. (2013) improved the method by using detritus boxes based on plastic containers and feeding juveniles with commercial phytoplankton. The application of this method to M. auricularia has produced three cohorts of juveniles (2014, 2015, and 2016); however, a high mortality was observed during the first year of study. Lavictoire et al. (2016), working on M. margaritifera, found that this method yields a relatively low number of individuals and requires intensive management, as has been the case also for M. auricularia. Young and Williams (1983) suggested that the early juvenile stage seems to be the most vulnerable to disturbances, so the stability that this method provides seems fundamental.
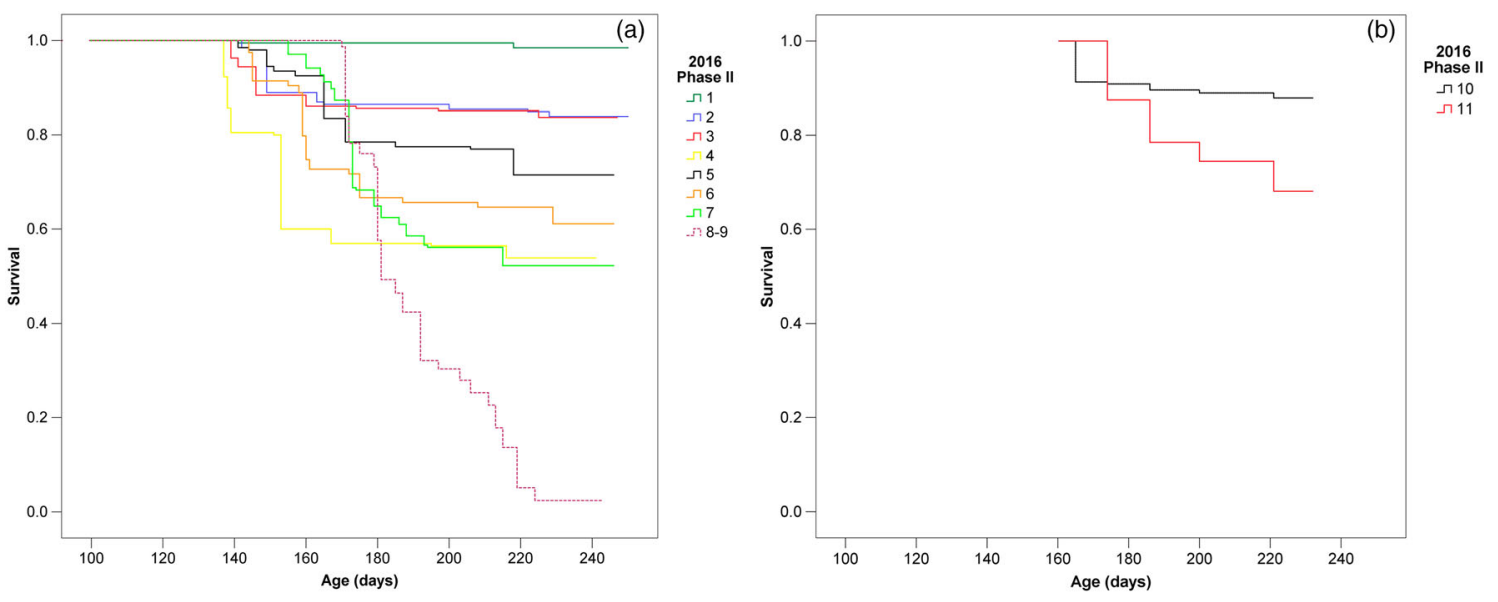

FIGURE 4 Proportion of Margaritifera auricularia juveniles surviving in phase II, year 2016. (a) Juveniles from cultures fed marine phytoplankton (starting day aquaria: 1 = 105 days; $2=110$ days; $3=117 ; 4=127 ; 5=128 ; 6=131 ; 7=134 ; 8-9=152$ ). (b) Juveniles from cultures fed freshwater phytoplankton (starting day both aquaria $=162$ days) 
The first recorded peak of high mortality occurred around day 100, suggesting this is the time period for moving from phase I (detritus boxes) to phase II. In the 0.5-L culture boxes, the resources are probably too rapidly consumed by juveniles, which attain a shell size up to $1 \mathrm{~mm}$, and then need further resources to avoid food shortage (Eybe et al., 2015). In 2016, growth and survival improved substantially in the treatment with a daily feeding rate, most probably also in relation to the earlier transfer to phase II. At this stage, the pumped water current might have facilitated the capture of suspended food. Feeding juveniles with freshwater phytoplankton should assist their adaptation to natural habitats when released. In fact, several authors have managed to breed other freshwater mussel species with this type of food (Kovitvadhi et al., 2006; O'Beirn, Neves, \& Steg, 1998). In the case of M. auricularia, the large size of the freshwater algae (S. quadricauda and $P$. viridis) might have resulted in a conglomerate, which was difficult for the juveniles to feed on (Nakamura, personal observation). Freshwater phytoplankton apparently does not have adverse effects on juvenile survival, as may occur with the presence of salts in the marine food, which can generate metabolic stress (Hart et al., 1991), especially as the amount of food needs to be increased after the first few months. However, in captive breeding, the balance between survival and growth must also be considered, as a faster growth in early juvenile instars may strongly reduce mortality later in colder periods (Schartum, Mortensen, Pittman, \& Jakobsen, 2016). In this study, juveniles fed with freshwater algae showed lower growth rates, well below average, so perhaps this food was less nutritious or less edible because of its larger size, than the selected marine algae. Consequently, freshwater phytoplankton might be disadvantageous as a food resource for the sake of growth, even though a higher proportion of juveniles survived (c. 0.7 survival in 100 days compared with 0.5-0.6 in the mussels fed with marine algae). Future studies should evaluate this issue, using mixtures of species close to those found in the natural environments where M. auricularia persists, and testing a combination of marine and freshwater algae, or higher daily feeding rates also using freshwater phytoplankton.

The presence of substrate and detritus, phytoplankton food and the use of river water increased the survival of M. auricularia juveniles. Therefore, future treatments aimed at their production must take these variables into account. With regard to water type, the best results were obtained with water from the main channel of the Ebro River, not from the CIA. These results were unexpected because the highest abundance of M. auricularia in the Ebro basin has been found in the $\mathrm{CIA}$, rather than in the main river. However, a high mortality has been reported since 2013 in this canal, where pollution and the presence of IAS, among other factors, have been considered potential causes of the mussel population decline (Nakamura, Guerrero, et al., 2018). It is possible, therefore, that water obtained from the Ebro River for the experiments had a better quality and enhanced the survival and growth of $M$. auricularia juveniles. As in $M$. margaritifera (Lavictoire et al., 2016), when detached from their fish host, juveniles of $M$. auricularia get buried in the substrate, thus achieving maximum stability of physical conditions (water flow) in their early stages. The lower survival in the treatment with additional aeration in 2014 might have produced increased disturbance, causing stress and reducing juvenile survival, even though bubbling was very gentle and near the water surface.

A diet with a mixture of several algal species is commonly recommended in captive breeding (Gatenby et al., 1997; 2003). In the present study, the mixture of seven different algae (Shellfish diet $1800 \AA$ : six species + Nannochloropsis $3600 \AA)$ provides a wide variety of chemical compounds, including fatty acids, proteins and lipids, as well as a diversity of food size items. Mair (2013) recommended the use of living algae, or alternatively a Shellfish $\operatorname{diet}{ }^{\circledR}$. However, this product is poor in polyunsaturated fatty acids and, consequently, adding living algae such as N. oleabundans is highly recommended (Mair, 2013). In the present study, Nannochloropsis sp. was used because it is known to have a high lipid content, especially polyunsaturated fatty acids, which are essential as nutritional components for freshwater organisms (Krienitz \& Wirth, 2006), and juvenile freshwater mussels in particular (Gatenby et al., 1997).

Juvenile survival was higher in treatments with substrate in the 2014 cohort when compared with those without. These results agree with those obtained by O'Beirn et al. (1998) for Villosa iris. Gatenby et al. (1996) suggested that the presence of fine sediments helps the digestive activity of juveniles by facilitating crushing of particles, and it may also facilitate pedal feeding. Jones, Mair, and Neves (2005) suggested that the presence of substrate might protect juveniles against predators, allowing them also to bury and adopt a position favouring filter feeding. Some controversy exists about the role of bacteria on the survival and growth of juvenile mussels: for example, Gatenby et al. (1996) considered that bacteria might not be very important whereas Nichols and Garling $(2000,2002)$ stated that they could be an important food resource. Vaughn and Hakenkamp (2001) indicated that some freshwater bivalve species supplement suspension feeding in the water column by feeding on organic detritus and bacteria in the sediments, especially in environments with high turbidity where the phytoplankton does not reach high densities. In addition, freshwater mussels in rivers filter more bacteria than pond species (Vaughn \& Hakenkamp, 2001). Eybe et al. (2013) also highlighted the role that detritus plays as a biological filter, owing to the presence of nitrifying bacteria that decrease metabolites, up to $50 \%$ in the case of ammonium, thus reducing the probability of high mortality by this toxic compound. In the present study, the concentration of nitrite and ammonium in the detritus boxes was always close to zero. So, in M. auricularia boxes, the possible major role as a biological filter was attributed to the substrate and not to detritus. The presence of substrate not only allows bacterial proliferation that may reduce the presence of metabolites, but juveniles can probably also use those bacteria as an additional food resource (Nakamura et al., 2015).

Other variables tested, i.e. density, feeding rate, and type of container, may be modified with no major effects on juvenile survival or growth, although some combinations have generated better results than others. Density plays an important role in phase I, because juveniles are very sensitive to interactions such as resource competition, which affects their survival and growth (Eybe et al., 2013, 2015). In 
this study, low densities $\left(0.2\right.$ ind. $\left.\mathrm{L}^{-1}\right)$ minimize these interactions, as those individuals that grow faster and consume a larger amount of resources may influence the survival of the smaller individuals in the same container, with less impact at lower densities. Eybe et al. (2015) performed tests with lower densities (100 juveniles per container) and justified this procedure in order to avoid competition for food. Thus, when lower juvenile densities are used, survival rates may increase.

Daily feeding produced better results than a weekly feeding, probably because it allowed a more efficient use of food resources. Juveniles can filter food particles from the water column, but also use pedal feeding by collecting organic matter available on the substrate. With weekly feeding, most food is soon deposited at the bottom (Nakamura, personal observation) and this is only available for pedal feeding, which is probably less efficient. The combination of both types of feeding leads to higher growth rates of juveniles (Vaughn \& Hakenkamp, 2001), as observed during phase II using marine phytoplankton in M. auricularia.

In summary, this study has shown that the ideal initial conditions for juveniles of M. auricularia must include filtered river water, substrate, detritus, and phytoplankton added daily, and the water must be renewed weekly. The type of container seems to have no effect on the survival of the juveniles but, for practical reasons (i.e. easier cleaning), glass containers are recommended.

\section{2 | Phase II}

According to Hastie and Young (2003), the pedal-to-filter feeding transition represents a critical period for the survival of juveniles in captivity, yet the age for this transition is still unknown for $M$. auricularia. Araujo et al. (2017) found that for M. margaritifera and Unio mancus (Lamarck, 1819) the second metamorphosis occurs at an age of 150-200 and 70 days, respectively. Lavictoire et al. (2016) reported that at age 12 months, M. margaritifera continue to feed with the foot and it is only at an age of around 25 months that it becomes a filter feeder, although gills are not completely formed until the mussels are 3 years old. Schartum et al. (2016) indicated that the shift in feeding behaviour is a critical transition for the survival of juveniles of $M$. margaritifera and that double feeding - both pedal and filtering - can decrease mortality, especially during winter. In the case of $M$. auricularia, the observations under a binocular microscope through the transparent shell, showed the primordia of gills in juveniles of $M$. auricularia as small as $500-600 \mu \mathrm{m}$ shell length, suggesting a possible start of mixed feeding at this size. From a shell length of $1 \mathrm{~mm}$ onwards, the mussels feed by filtering but without abandoning pedal feeding, as suggested by the grooves observed in the substrate in phase II. The incorporation of circulating water in the aquaria is a very important factor for the rapid growth of juveniles by facilitating filtration. This matches what happens in the natural environment where juvenile mussels take advantage of the interstitial water flow associated with fine particulate organic matter (Yeager, Cherry, \& Neves, 1994), spending less energy and facilitating ingestion by orienting towards the current (Englund \& Heino, 1996; Vaughn \& Hakenkamp, 2001).

High mortalities in juvenile freshwater mussels may have many causes, including hypoxia, metabolite accumulation (Eybe et al., 2013), and the transition process during the second metamorphosis in the laboratory, which many juveniles cannot overcome (Araujo et al., 2017). In the future, more studies are needed to assess the importance of this transition phase to decrease such high mortality rates in captivity.

In a previous study on captive breeding of M. auricularia, Araujo et al. (2003) obtained viable juveniles and kept them alive for up to 4-6 weeks; these eventually reached a shell length of $325 \mu \mathrm{m}$ at the end of that period. Nakamura et al. (2012) grew some juveniles up to $300 \mu \mathrm{m}$ in 6 weeks and up to $1 \mathrm{~mm}$ in 140 days. In the present study, the mean length at week 6 was approximately $440 \mu \mathrm{m}$. This larger size probably results from supplementary feeding, based on phytoplankton and detritus, which allows juveniles to grow faster. These growth rates may be compared with those described for $M$. margaritifera raised in captivity, although freshwater pearl mussels attain shorter lengths than M. auricularia (Outeiro, Ondina, Fernández, Amaro, \& San Miguel, 2007). Hruska (1999) and Eybe et al. (2013) reported a growth of c. $1 \mathrm{~mm}$ in about 16-20 weeks for $M$. margaritifera, but lower rates were observed by Schmidt and Vandré (2010) (maximum lengths of $800 \mu \mathrm{m}$ for juveniles kept for 4 months in the laboratory). In the present study, variable growth was recorded for M. auricularia at week 16: juveniles reached 556-609 $\mu \mathrm{m}$ in 2014, 726-818 $\mu \mathrm{m}$ in 2015 and 1400-1500 $\mu \mathrm{m}$ in 2016. Differences between years may be related to the implementation of phase II, facilitating the intake of daily food and therefore increasing growth rate. Such rise in the growth rate of juveniles is important to achieve before the first winter, as it increases survival probability when facing harsher conditions (Schartum et al., 2016). With respect to survival, Eybe et al. (2013) reported a rate of $80 \%$ at 110 days for M. margaritifera using detritus boxes. In this study, at 100 days the highest recorded survival was almost $60 \%$. Lavictoire et al. (2016), comparing survival rates of different freshwater mussels, showed that mortality can be variable with survival rates from 10 to $80 \%$ after $100-200$ days in captivity. In fact, the high mortality experienced by juveniles during the first year remains an important obstacle to the successful development of captive breeding of freshwater mussels. Further work and exchange of experiences and methodologies are needed to reduce the high mortality rates during the first year of growth.

Once the juveniles reach a larger size, two further steps are planned towards their successful transfer to the natural environment. Phase III will consist in increasing the volume and therefore the amount of food where the juveniles are kept, maintaining the same type of substrate, water, and daily feeding. Once a shell size of 2-3 cm is reached, phase IV will begin, which will test adaptation to the natural environment using an open system with natural river water and without extra artificial food. These procedures will need a periodic control of survival to assess whether successful reintroduction and population recovery of $M$. auricularia can be achieved in the near future. 


\subsection{Conservation importance}

The captive breeding of freshwater mussels should not be regarded as the only solution to conserve these endangered organisms (Strayer et al., 2019). The methods used both for the detritus boxes (phase I) and phase II, require a significant investment of time, logistics (including space to keep the cultures at controlled temperatures) and personnel. The lack of recruitment in natural habitats indicates that these are probably not suitable for all M. auricularia life stages, and therefore captive breeding must be complemented by a series of actions aimed at the potential habitats to achieve successful reintroduction of laboratory-reared juveniles. Such actions include the restoration of river dynamics and hydromorphology, an increase of floodplain habitats, improving water quality, and assisting the recovery of microhabitats by ensuring well-oxygenated substrates and a decrease of suspended solids (Dudgeon et al., 2006; Strayer et al., 2019). Remedial actions should remove the likely cause(s) for species decline (Bolland et al., 2010), so the management of fish host populations should also be included as a key management action in order to restore the reproductive potential of freshwater mussels in their natural habitats (Ferreira-Rodríguez et al., 2019).

In Europe, populations of M. auricularia are in decline (Prié et al., 2018), and the situation in the Ebro basin has recently become critical. Since 2013, high mortality rates of adults have been recorded and, every year, a large number of dead individuals have been found for this species and for other freshwater mussels such as Potomida littoralis (Cuvier 1798), Anodonta anatina (Linnaeus, 1758) and Unio mancus (Nakamura, Guerrero, et al., 2018). The possible causes of these mortalities are still unknown, but they may include pollution, climate change, diseases, or the impact of the Asian clam Corbicula spp., among other possibilities.

The results reported here may become a key management tool to improve the conservation status of $M$. auricularia in the Ebro River basin. Similar methods can be applied to other M. auricularia populations or other endangered freshwater mussels (e.g. M. marocana) with similar life-cycle traits (Sousa et al., 2016; 2018). These captive programmes and the later release of reared juveniles into natural habitats should only be implemented after the restoration of abiotic and biotic conditions, to allow the successful colonization of $M$. auricularia and the recovery of their populations in the natural habitat.

\section{ACKNOWLEDGEMENTS}

This project was funded by the Government of Aragón, Department of Rural Development and Sustainability and carried out by the Environmental Service Department of SARGA. Special thanks go to Manuel Alcántara, Miguel Ángel Muñoz, Ester Ginés, Carlos Catalá, and Juan Pablo de la Roche, who were involved in the project. The authors appreciate the work of the reviewer and editor who improved the quality of the manuscript. The Aragón's forest rangers are thanked for their assistance during fieldwork.

\section{ORCID}

Keiko Nakamura (D) https://orcid.org/0000-0001-5037-3516

Francesc Mesquita-Joanes (D) https://orcid.org/0000-0001-7168-1980

Ronaldo Sousa (D) https://orcid.org/0000-0002-5961-5515

Imanol Ruiz-Zarzuela (D) https://orcid.org/0000-0002-6314-6395

Ignacio de Blas (D) https://orcid.org/0000-0002-1204-4356

\section{REFERENCES}

Altaba, C. R. (1990). The last known population of Margaritifera auricularia: A conservation priority. Biological Conservation, 52, 271-286. https:// doi.org/10.1016/0006-3207(90)90072-W

Altaba, C. R. (1997). Al límit de l'extinció: Margaritifera auricularia (Bivalvia: Unionoida). Butlletí de la Institució Catalana d'Història Natural, 65, 137-148.

Altaba, C. R., \& López, M. A. (2001). Experimental demonstration of viability for the endangered giant pearlmussel Margaritifera auricularia (Bivalvia: Unionoida) in its natural habitat. Bolletí de la Societat d'Història Natural de les Balears, 44, 15-21.

Araujo, R., \& Álvarez-Cobelas, M. (2016). Influence of flow diversions on giant freshwater pearl mussel populations in the Ebro river, Spain. Aquatic Conservation: Marine and Freshwater Ecosystems, 26, 1145-1154. https://doi.org/10.1002/aqc.2622

Araujo, R., Bragado, D., \& Ramos, M. A. (2001). Identification of the river blenny Salaria fluviatilis as a host to the glochidia of Margaritifera auricularia. Journal of Molluscan Studies, 67, 128-129. https://doi.org/ 10.1093/mollus/67.1.128

Araujo, R., Cámara, N., \& Ramos, M. A. (2002). Glochidium metamorphosis in the endangered freshwater mussel Margaritifera auricularia (Spengler, 1793): A histological and scanning electron microscopy study. Journal of Morphology, 254, 259-265. https://doi.org/10.1002/ jmor.10031

Araujo, R., Campos, M., Feo, C., Varela, C., Soler, J., \& Ondina, P. (2017). Who wins in the weaning process? Juvenile feeding morphology of two freshwater mussel species. Journal of Morphology, 279, 4-16. https://doi.org/10.1002/jmor.20748

Araujo, R., Feo, C., Pou, Q., \& Campos, M. (2015). Conservation of two endangered European freshwater mussels (Bivalvia: Unionidae): A three-year, semi-natural breeding experiment. The Nautilus, 129, 126-135.

Araujo, R., Quirós, M., \& Ramos, M. A. (2003). Laboratory propagation and culture of juveniles of the endangered freshwater mussel Margaritifera auricularia (Spengler, 1793). Journal of Conchology, 38, 53-60.

Araujo, R., \& Ramos, M. A. (1998). Margaritifera auricularia (Unionoidea, Margaritiferidae), the giant freshwater pearl mussel rediscovered in Spain. Graellsia, 54, 129-130. https://doi.org/10.3989/graellsia.1998. v54.i0.354

Araujo, R., \& Ramos, M. A. (2000a). Status and conservation of the relict giant European freshwater pearl mussel Margaritifera auricularia (Spengler, 1793). Biological Conservation, 96, 233-239. https://doi. org/10.1016/S0006-3207(00)00075-6

Araujo, R., \& Ramos, M. A. (2000b). A critical revision of the historical distribution of Margaritifera auricularia (Spengler, 1793) (Mollusca: Margaritiferidae) based on museum specimens. Journal of Conchology, 37, 49-59.

Araujo, R., \& Ramos M. A. (2001). Action plan for Margaritifera auricularia. Convention on the Conservation of European Wildlife and Natural Habitats (Bern Convention). Nature and Environment no. 117, Council of Europe Publishing, Strasbourg. 
Araujo, R., Reis, J., Machordom, A., Toledo, C., Madeira, M. J., Gomez, I., .. Ayala, I. (2009). Las náyades de la península Ibérica. Iberus, 27, 7-72.

Barnhart, M. C. (2006). Buckets of muckets: A compact system for rearing juvenile freshwater mussels. Aquaculture, 254, 227-233. https://doi. org/10.1016/j.aquaculture.2005.08.028

Beck, K., \& Neves, J. (2003). An evaluation of selective feeding by three age-groups of the rainbow mussel, Villosa iris. North American Journal of Aquaculture, 65, 203-209. https://doi.org/10.1577/C02-031

Bogan, A. E. (1993). Freshwater bivalve extinctions (Mollusca: Unionoida): A search for causes. American Zoologist, 33, 599-609. https://doi.org/ 10.1093/icb/33.6.599

Bogan, A. E. (2008). Global diversity of freshwater mussels (Mollusca, Bivalvia) in freshwater. Hydrobiology, 595, 139-147. https://doi.org/ 10.1007/s10750-007-9011-7

Bolland, J. D., Bracken, L. J., Marin, R., \& Lucas, M. C. (2010). A protocol for stocking hatchery reared freshwater pearl mussel Margaritifera margaritifera. Aquatic Conservation: Marine and Freshwater Ecosystems, 20, 695-707. https://doi.org/10.1002/aqc.1139

Cochet, G. (2001). Margaritifera auricularia sur le cours de la Vienne. Bilan des connaissances. Impact des amenagements. Gestion et protection. Direction Regionale de L'Environnement.

Council of the European Communities (1992). Council Directive 92/43/ EEC of 21 May 1992 on the conservation of natural habitats and of wild fauna and flora. Official Journal of the European Communities, L206, 7-50.

Denic, M., Taeubert, J. E., Lange, M., Thielen, F., Scheder, C., Gumpinger, C., \& Geist, J. (2015). Influence of stock origin and environmental conditions on the survival and growth of juvenile freshwater pearl mussels (Margaritifera margaritifera) in a cross-exposure experiment. Limnologica, 50, 67-74. https://doi.org/10.1016/j.limno.2014.07.005

Dudgeon, D., Arthington, A. H., Gessner, M. O., Kawabata, Z. I., Knowler, D. J., Lévêque, C., ... Sullivan, C. A. (2006). Freshwater biodiversity: Importance, threats, status and conservation challenges. Biological Reviews, 81, 163-182. https://doi.org/10.1017/S1464793105006950

Elvira, B., Almodóvar, A., \& Lobón-Cerviá, J. (1991). Recorded distribution of sturgeon (Acipenser sturio L.,1758) in the Iberian Peninsula and actual status in Spanish waters. Archiv für Hydrobiologie, 121, 253-258.

Englund, V. P. M., \& Heino, M. P. (1996). Valve movement of the freshwater mussel Anodonta anatina: A reciprocal transplant experiment between lake and river. Hydrobiologia, 328, 49-56. https://doi.org/ 10.1007/BF00016899

Eybe, T., Thielen, F., Bohn, T., \& Sures, B. (2013). The first millimeter - rearing juvenile freshwater pearl mussels (Margaritifera margaritifera L.) in plastic boxes. Aquatic Conservation: Marine and Freshwater Ecosystems, 23, 964-975. https://doi.org/10.1002/aqc.2384

Eybe, T., Thielen, F., Bohn, T., \& Sures, B. (2015). Influence of the excystment time on the breeding success of juvenile freshwater pearl mussels (Margaritifera margaritifera). Aquatic Conservation: Marine and Freshwater Ecosystems, 25, 21-30. https://doi.org/10.1002/aqc.2471

Ferreira-Rodríguez, N., Akiyama, B. Y., Aksenova, O., Araujo, R., Barnhart, C., Bespalaya, Y., ... Clearwater, S. J. (2019). Research priorities for freshwater mussel conservation assessment. Biological Conservation, 231, 77-87. https://doi.org/10.1016/j.biocon.2019.01.002

Gatenby, C. M., Neves, R. J., \& Parker, B. C. (1996). Influence of sediment and algal food on cultured juvenile freshwater mussels. Journal of the North American Benthological Society, 15, 597-609. https://doi.org/ $10.2307 / 1467810$

Gatenby, C. M., Orcutt, D. M., Kreeger, D. A., Parker, B. C., Jones, V. A., \& Neves, R. J. (2003). Biochemical composition of three algal species proposed as food for captive freshwater mussels. Journal of Applied Phycology, 15, 1-11. https://doi.org/10.1023/A:1022929423011
Gatenby, C. M., Parker, B. C., \& Neves, R. J. (1997). Growth and survival of juvenile rainbow mussels, Villosa iris (Bivalvia: Unionidae) reared on algal diets and sediment. American Malacological Bulletin, 14, 57-66.

Geist, J. (2010). Strategies for the conservation of endangered freshwater pearl mussels (Margaritifera margaritifera L.): A synthesis of conservation genetics and ecology. Hydrobiologia, 644, 69-88. https://doi.org/ 10.1007/s10750-010-0190-2

Geist, J. (2011). Integrative freshwater ecology and biodiversity conservation. Ecological Indicators, 11, 1507-1516. https://doi.org/10.1016/j. ecolind.2011.04.002

Geist, J., \& Auerswald, K. (2007). Physicochemical stream bed characteristics and recruitment of the freshwater pearl mussel (Margaritifera margaritifera). Freshwater Biology, 52, 2299-2316. https://doi.org/ 10.1111/j.1365-2427.2007.01812.x

Gómez, I., \& Araujo, R. (2008). Channels and ditches as the last shelter for freshwater mussels. The case of $M$. auricularia and other freshwater mussels inhabiting the mid Ebro river basin, Spain. Aquatic Conservation: Marine and Freshwater Ecosystems, 18, 658-670. https://doi.org/ 10.1002/aqc.860

Gum, B., Lange, M., \& Geist, J. (2011). A critical reflection on the success of rearing and culturing juvenile freshwater mussels with a focus on the endangered freshwater pearl mussel (Margaritifera margaritifera L.). Aquatic Conservation: Marine and Freshwater Ecosystems, 21, 743-751. https://doi.org/10.1002/aqc.1222

Haas, F. (1916). Sobre una concha fluvial interesante (Margaritana auricularia Spglr.) y su existencia en España. Boletín de la Sociedad Aragonesa de Ciencias Naturales, 15, 33-45.

Haas, F. (1917). Estudios sobre las náyades del Ebro. Boletín de la Sociedad Aragonesa de Ciencias Naturales, 16, 71-82.

Hart, B. T., Bailey, P., Edwards, R., Hortle, K., James, K., McMahon, A., ... Swadling, K. (1991). A review of the salt sensitivity of the Australian freshwater biota. Hydrobiologia, 210, 105-144. https://doi.org/ 10.1007/BF00014327

Hastie, L. C., \& Young, M. R. (2003). Conservation of the freshwater pearl mussel I: Captive breeding techniques. In Conserving Natura 2000 Rivers. Ecology Series no. 2. Peterborough: English Nature.

Howard, J. K., \& Coffey, K. M. (2006). The functional role of native freshwater mussels in the fluvial benthic environment. Freshwater Biology, 51, 460-474. https://doi.org/10.1111/j.1365-2427.2005.01507.x

Hruska, J. (1999). Nahrungsansprüche der Flußperlmuschel und deren halbnatürliche Aufzucht in der Tschechischen Republik. Heldia, 6/4, 69-79.

Hruska, J. (2001). Experience of semi-natural breeding program of freshwater pearl mussel in the Czech Republic. Die Flussperlmuschel in Europa: Bestandssituation und Schutzmaßnahmen. Kongressband (pp. 69-75). Freiburg: WWA Hof, Albert-Ludwigs Universität.

Jones, J. W., Mair, R., \& Neves, R. (2005). Factors affecting survival and growth of juvenile freshwater mussels cultured in recirculating aquaculture systems. North American Journal of Aquaculture, 67, 210-220. https://doi.org/10.1577/A04-055.1

Kovitvadhi, S., Kovitvadhi, U., Sawangwong, P., Thongpan, A., \& Machado, J. (2006). Optimization of diet and culture environment for larvae and juvenile freshwater pearl mussels, Hyriopsis (Limnoscapha) myersiana Lea, 1856. Invertebrate Reproduction and Development, 49, 61-70. https://doi.org/10.1080/07924259.2006.9652194

Krienitz, L., \& Wirth, M. (2006). The high content of polyunsaturated fatty acids in Nannochloropsis limnetica (Eustigmatophyceae) and its implication for food web interactions, freshwater aquaculture and biotechnology. Limnologica - Ecology and Management of Inland Waters, 36, 204-210. https://doi.org/10.1016/j.limno.2006.05.002 
Kyle, R., Reid, N., O'Connor, N., \& Roberts, D. (2017). Development of release methods for captive-bred freshwater pearl mussels (Margaritifera margaritifera). Aquatic Conservation: Marine and Freshwater Ecosystems, 27, 492-501. https://doi.org/10.1002/aqc.2704

Lavictoire, L., Moorkens, E., Ramsey, A. D., Sinclair, B., \& Sweeting, R. A. (2016). Effects of substrate size and cleaning regime on growth and survival of captive-bred juvenile freshwater pearl mussels, Margaritifera margaritifera (Linnaeus, 1758). Hydrobiologia, 766, 89-102. https://doi. org/10.1007/s10750-015-2445-4

Liberty, A. J., Ostby, B. J., \& Neves, R. J. (2007). Determining a suitable substrate size and sampling frequency for rearing juvenile rainbow mussels Villosa iris. North American Journal of Aquaculture, 69, 44-52. https:// doi.org/10.1577/A05-090.1

Lopes-Lima, M., Burlakova, L. E., Karatayev, A. Y., Mehler, K., Seddon, M., \& Sousa, R. (2018). Conservation of freshwater bivalves at the global scale: Diversity, threats and research needs. Hydrobiologia, 810, 1-14. https://doi.org/10.1007/s10750-017-3486-7

Lopes-Lima, M., Teixeira, A., Froufe, E., Lopes, A., Varandas, S., \& Sousa, R. (2014). Biology and conservation of freshwater bivalves: Past, present and future perspectives. Hydrobiologia, 735, 1-13. https://doi.org/ 10.1007/s10750-014-1902-9

Lopes-Lima, M., Sousa, R., Geist, J., Aldridge, D. C., Araujo, R., Bergengren, J., ... Zogaris, S. (2017). Conservation status of freshwater mussels in Europe: State of the art and future challenges. Biological Reviews, 92, 572-607. https://doi.org/10.1111/brv.12244

López, M. A., \& Altaba, C. R. (2005). Fish host determination for Margaritifera auricularia (Bivalvia: Unionoida): Results and implications. Bollettino Malacologico, 41, 89-98.

López, M. A., Altaba, C. R., Rouault, T., \& Gisbert, E. (2007). The European sturgeon Acipenser sturio is a suitable host for the glochidia of the freshwater pearl mussel Margaritifera auricularia. Journal of Molluscan Studies, 73, 207-209. https://doi.org/10.1093/mollus/eym007

Lydeard, C., Cowie, R. H., Ponder, W. F., Bogan, A. E., Bouchet, P., Clark, S. A., ... Thompson, F. G. (2004). The global decline of nonmarine mollusks. Bioscience, 54, 321-330. https://doi.org/10.1641/00063568(2004)054[0321:TGDONM]2.0.CO;2

Machordom, A., Araujo, R., Erpenbeck, D., \& Ramos, M. A. (2003). Phylogeography and conservation genetics of endangered European Margaritiferidae (Bivalvia: Unionoidea). Biological Journal of the Linnean Society, 78, 235-252. https://doi.org/10.1046/j.1095-8312.2003. 00158.x

Mair, R. A. (2013). A suitable diet and culture system for rearing juvenile freshwater mussels at White Sulphur Springs National Fish Hatchery, West Virginia (PhD thesis). Virginia Polytechnic Institute and State University.

Modesto, V., Ilarri, M., Souza, A. T., Lopes-Lima, M., Douda, K., Clavero, M., $\&$ Sousa, R. (2018). Fish and mussels: Importance of fish for freshwater mussel conservation. Fish and Fisheries, 19, 244-259. https://doi.org/ 10.1111/faf.12252

Moorkens, E. (2011). Margaritifera margaritifera. The IUCN Red List of Threatened Species 2011: E.T12799A3382660. Downloaded on 11 April 2018

Moorkens, E. (2018). Short-term breeding: Releasing post-parasitic juvenile Margaritifera into ideal small-scale receptor sites: A new technique for the augmentation of declining populations. Hydrobiologia, 810 145-155. https://doi.org/10.1007/s10750-017-3138-y

Nakamura, K., Cucala, L., Mestre, A., Mesquita-Joanes, F., Elbaile, E. Salinas, C., \& Muñoz, M. A. (2018). Modelling growth in the critically endangered freshwater mussel Margaritifera auricularia (Spengler, 1793) in the Ebro basin. Hydrobiologia, 810, 375-391. https://doi. org/10.1007/s10750-017-3103-9
Nakamura, K., Elbaile, E., Muñoz, M. A., Catalá, C., \& Salinas, C. (2012). Captive breeding of the endangered pearl mussel Margaritifera auricularia (Spengler, 1793). Large scale laboratory production of juveniles. In A. Teixeira, M. Lopes-Lima, S. Varandas, R. Sousa, E. Froufe, \& F. Teiga (Eds.), International meeting on biology and conservation of freshwater bivalves: Book of abstracts. Portugal: Bragança.

Nakamura, K., \& Guerrero, J. (2008). Margaritifera auricularia, un difícil reto de conservación. Quercus, 265, 20-25.

Nakamura, K., Guerrero, J., Alcántara, M., Muñoz, M. A., \& Elbaile, E. (2018). Tiempos de incertidumbre para la náyade Margaritifera auricularia. Quercus, 383, 16-24.

Nakamura, K., Muñoz, M. A., Ruiz, I., de Blas, I., Elbaile, E., \& Salinas, C. (2015). The first year of Margaritifera auricularia (Spengler, 1793). Breeding in captivity in Aragón, Spain. 2nd International Seminar, Rearing of unionoid mussels. 24th-26th November 2015, Clervaux (Luxembourg).

Neves, R. J., Bogan, A. E., Williams, J. D., Ahlstedt, S. A., \& Hartfield, P. W. (1997). Status of aquatic mollusks in the southeastern United States: A downward spiral of diversity. In G. W. Benz, \& D. E. Collins (Eds.), Aquatic fauna in peril: The southeastern perspective (pp. 43-85). Decatur (GA): Lenz Design and Communications.

Nichols, S. J., \& Garling, D. (2000). Food web dynamics and trophic-level interactions in a multispecies community of freshwater unionids. Canadian Journal of Zoology, 78, 871-882. https://doi.org/10.1139/ z99-256

Nichols, S. J., \& Garling, D. (2002). Evaluation of substitute diets for live algae in the captive maintenance of adult and subadult Unionidae. Journal of Shellfish Research, 21, 875-881.

Nienhuis, J. A. (2003). The rediscovery of Spengler's freshwater pearlmussel Pseudunio auricularius (Spengler, 1793) (Bivalvia, Unionoidea, Margaritiferidae) in two river systems in France, with an analysis of some factors causing its decline. Basteria, 67, 67-86.

O'Beirn, F. X., Neves, R. J., \& Steg, M. B. (1998). Survival and growth of juvenile freshwater mussels (Unionidae) in a recirculating aquaculture system. American Malacological Bulletin, 14, 165-171.

Outeiro, A., Ondina, P., Fernández, C., Amaro, R., \& San Miguel, E. (2007). Population density and age structure of the freshwater pearl mussel, Margaritifera margaritifera, in two Iberian rivers. Freshwater Biology, 53, 485-496. https://doi.org/10.1111/j.1365-2427.2007.01913.x

Preston, S. J., Keys, A., \& Roberts, D. (2007). Culturing freshwater pearl mussel Margaritifera margaritifera: A breakthrough in the conservation of an endangered species. Aquatic Conservation: Marine and Freshwater Ecosystems, 17, 539-549. https://doi.org/10.1002/aqc.799

Prié, V. (2010). Margaritifera auricularia. The IUCN Red List of Threatened Species 2010:e.T12798A3381899. https://doi.org/10.2305/IUCN. UK.2010-4.RLTS.T12798A3381899.en. Downloaded on 11 April 2018.

Prié, V., Bousquet, P., Serena, A., Tabacchi, E., Jourde, P., Adam, B., ... Cochet, G. (2010). Nouvelles populations de grande mulette Margaritifera auricularia (Spengler, 1793) (Bivalvia, Margaritiferidae) découvertes dans le sud-ouest de la France. MalaCo, 6, 294-297.

Prié, V., Soler, J., Araujo, R., Cucherat, X., Philippe, L., Patry, N., ... Wantzen, K. M. (2018). Challenging exploration of troubled waters: A decade of surveys of the giant freshwater pearl mussel Margaritifera auricularia in Europe. Hydrobiologia, 810, 157-175. https://doi.org/10.1007/ s10750-017-3456-0

Schartum, E., Mortensen, S., Pittman, K., \& Jakobsen, P. J. (2016). From pedal to filter feeding: Ctenidial organogenesis and implications for feeding in the postlarval freshwater pearl mussel Margaritifera margaritifera (Linnaeus, 1758). Journal of Molluscan Studies, 83, 36-42. https://doi.org/10.1093/mollus/eyw037 
Scheder, C., Lerchegger, B., Jung, M., Csar, D., \& Gumpinger, C. (2014) Practical experience in the rearing of freshwater pearl mussels (Margaritifera margaritifera): Advantages of a work-saving infection approach, survival, and growth of early life stages. Hydrobiologia, 735, 203-211. https://doi.org/10.1007/s10750-013-1516-7

Schmidt, C., \& Vandré, R. (2010). Ten years of experience in the rearing of young freshwater pearl mussels (Margaritifera margaritifera). Aquatic Conservation: Marine and Freshwater Ecosystems, 20, 735-747. https://doi.org/10.1002/aqc.1150

Sime, I. (2016). Fresh water pearl mussel. Version 1.0. In M. J. Gaywood, P. J. Boon, D. B. A. Thompson, \& I. M. Strachan (Eds.), The species action framework handbook. Battleby, Perth: Scottish Natural Heritage. Chapter 13

Soler, J., Boisneau, C., Wantzen, K. M., \& Araujo, R. (2018). Gasterosteus aculeatus Linnaeus, 1758, a new host fish for the endangered Margaritifera auricularia (Spengler, 1793) (Unionoida: Margaritiferidae). Journal of Molluscan Studies, 84, 490-493. https://doi.org/10.1093/mollus/eyy038

Soler, J., Wantzen, K. M., Jugé, P., \& Araujo, R. (2018). Brooding and glochidia release in Margaritifera auricularia (Spengler, 1793) (Unionoida: Margaritiferidae). Journal of Molluscan Studies, 84, 182-189. https://doi.org/10.1093/mollus/eyy008

Sousa, R., Teixeira, A., Santos, A., Benaissa, H., Varandas, S., Ghamizi, M., ... Lopes-Lima, M. (2018). Oued Bouhlou: A new hope for the Moroccan pearl mussel. Aquatic Conservation: Marine and Freshwater Ecosystems, 28, 247-251. https://doi.org/10.1002/aqc.2825

Sousa, R., Varandas, S., Teixeira, A., Ghamizi, M., Froufe, E., \& Lopes-Lima, M. (2016). Pearl mussels (Margaritifera marocana) in Morocco: Conservation status of the rarest bivalve in African fresh waters. Science of the Total Environment, 547, 405-412. https://doi.org/ 10.1016/j.scitotenv.2016.01.003

Strayer, D. L., Downing, J. A., Haag, W. R., King, T. L., Layzer, J. B., Newton, T. J., \& Nichols, S. J. (2004). Changing perspectives on pearly mussels,
North America's most imperiled animals. Bioscience, 54, 429-439. https://doi.org/10.1641/0006-3568(2004)054[0429:CPOPMN]2.0. $\mathrm{CO} ; 2$

Strayer, D. L., Geist, J., Haag, W. R., Jackson, J. K., \& Newbold, J. D. (2019). Essay: Making the most of recent advances in freshwater mussel propagation and restoration. Conservation Science and Practice, 1(7), 1-9. https://doi.org/10.1111/csp2.53D

Thielen, F. (Ed.) (2011). Rearing of unionoid mussels (with special emphasis on the freshwater pearl mussel Margaritifera margaritifera). Luxembourg. Ferrantia, 64.

Thomas, G. R., Taylor, J., \& Garcia de Leaniz, C. (2010). Captive breeding of the endangered freshwater pearl mussel Margaritifera margaritifera. Endangered Species Research, 12, 1-9. https://doi.org/10.3354/ esr00286

Vaughn, C. C., \& Hakenkamp, C. C. (2001). The functional role of burrowing bivalves in freshwater ecosystems. Freshwater Biology, 46, 1431-1446. https://doi.org/10.1046/j.1365-2427.2001.00771.x

Yeager, M. M., Cherry, D. S., \& Neves, R. J. (1994). Feeding and burrowing behaviors of juvenile rainbow mussels Villosa iris (Bivalvia: Unionidae). Journal of the North American Benthological Society, 13, 217-222. https://doi.org/10.2307/1467240

Young, M. R., \& Williams, J. (1983). The status and conservation of the freshwater pearl mussel in Great Britain. Biological Conservation, 25 , 35-52. https://doi.org/10.1016/0006-3207(83)90029-0

How to cite this article: Nakamura K, Elbaile E, Salinas C, et al. Captive breeding of Margaritifera auricularia (Spengler, 1793) and its conservation importance. Aquatic Conserv: Mar Freshw Ecosyst. 2019;29:1771-1784. https://doi.org/10.1002/aqc.3209 